\title{
Interaction Among Universities, Government and Spin-off Companies in a Brazilian Context to Generate Sports Innovation
}

\author{
Branca Terra', Luis Alberto Batista², Sergio Ricardo Cortines Campos ${ }^{3}$, Mariza Almeida ${ }^{4}$
}

\begin{abstract}
The aim of this paper is to describe a study into Brazilian academic spin offs that are developing innovative products and services for the sports market, based on the triple helix model. The results show the characteristics of the products and services of the spin offs in the sporting field that were studied, their innovation sources and the financial resources they have received, as well as the university and government role in stimulating these innovations.
\end{abstract}

Keywords: innovation; sports innovation; spin-offs; university-industry-government relations; triple helix.

\footnotetext{
'Rio de Janeiro State University - UERJ. Rua São Francisco Xavier, 525 Bloco B room 8024, Rio de Janeiro - RJ, CEP 20550-0 3 , Brazil. Phone: 55 2I 23340662/23340360/78850923.e-mail: 'brancaterra@gmail.com, ${ }^{2}$ e-mail: bmc_ef@yahoo.com.br ${ }^{3}$ Art in Surf. e-mail: cortinescampos@yahoo.com.br ${ }^{4}$ Corresponding author. Federal University of the State of Rio de Janeiro - Unirio. Avenida Pasteur, 458, Urca, Rio de Janeiro, RJ, Brazil, CEP22290-240.Phone/Fax: 55 21-2530-805I.E-mail: mariza.almeida@uniriotec.br
} 


\section{Introduction}

The prospect of hosting the football World Cup in 2014 and the summer Olympic and Paralympic Games in 2016, as well as the experience of hosting the Pan American Games in 2007, has stimulated discussion in Brazil about the holding of such 'mega-events' and their legacy for the cities and regions that host them . This debate has extended into the academic sphere, with scientific gatherings taking place and publications on the topic being released (DaCosta et al, 2008). At the same time, agencies and government bodies that support scientific research have included among their tendering invitations themes devoted specifically to innovation in the sporting field, on the understanding that the country could use this opportunity to become a producer of sports solutions and not just a buyer.

There is a favorable environment in Brazil for the stimulating of technological innovation in business, including nonrepayable financial resources, subject to approval and the regulations of the Innovation Law $(2004,2005)$ and the launching of federal government economic programs, such as the Plan for a Greater Brazil (20II - 20I5), which seeks to provide continuity and also expand upon the industrial policy measures that had been introduced previously: PITCE - Industrial, Technological and Foreign Trade Policy (20032007) and PDP - Policy for the Development of Production (2008-2010) .

At the same time, there are a considerable number of incubators in Brazil. According to the most recent survey, in $20 \mathrm{II}$, there are 384 incubators of various kinds (technological, traditional, mixed or cultural), hosting 2,640 companies under incubation and I, 124 associated companies. These companies, under incubation and associated, generate 16,394 jobs. And to this number one can add another 29,905 jobs in the companies that have already been incubated. The revenue generated amounts to $R \$ 533$ million for the companies under incubation and $R \$ 4$.I billion for those that have already been incubated. According to the same survey, with regard to innovation, it has been found that $15 \%$ of the companies innovate on a global level, $55 \%$ relate to the country's domestic market and $28 \%$ at the local level (Anprotec, 20I2).

It has also been observed that, according to the most recent data available, for 2004, a significant proportion of the incubators $(72 \%)$ are formally linked to universities (Anprotec, 2004), which facilitates the development of spin offs as instruments for the transferring of the know-how and technology generated at those institutions (Etzkowitz et al, 2005).
Academic publications on the legacy of sporting megaevents and addressing their impact have helped to make this a controversial topic. Such studies have covered the social, economic, environmental and cultural dimensions, among others. Behind the scene of hosting some very successful games, there were a large number of initiatives and ventures with various outcomes. Previous experience of countries that have hosted international sporting competition megaevents has shown that the legacy for the host city also covers impacts generated by new entrepreneurial performance in the region, which can affect various economic sectors (Spilling, 1996).

The present global context of professional competitive sports involves considerable Science, Technology \& Innovation (S, T \& I) development, yielding improved performance from the athletes, which in turn provides sporting success that generates new business opportunities. Hence, the development by companies of closer relations with the universities and government can lead to the creation of new technology and products for the sporting field, spurred by the research potential of the academic institutions and government support. Such The firms that come about (academic spin offs) generate knowledge of the sporting field, through the interaction between university-industry-government, and are linked to a very broad range of knowledge (health sciences, life sciences, applied social sciences, engineering, humanities, linguistics, arts and literature and arts, earth sciences, mathematics, agricultural sciences and others). These knowledge-based firms are linked to the research and development of innovative ideas and are usually, located in incubators, thus becoming business spin-offs.

Business spin-offs should seek, through university-industrygovernment interaction, to attain the production of knowledge required for business success. For this to happen, universities must be alert to opportunities for innovation in sport and encourage professors and students to create academic organizational structures for developing teaching research and economic development focused on innovation in sport (Etzkowitz, 2008).

Meanwhile, the process by which the results of research, or a technical idea with potential value developed in a university, are converted into one or more commercially successful products, through the generation of a spin-off company, is highly complex, poorly documented, and little studied in emerged developing countries, including Brazil, (Botelho and Almeida, 2010).

Major sporting events, because they are trans professional, are directly linked to various economic segments, since their inherent activities require a variety of products, ranging from clothing to medical technology and infrastructural services,

ISSN: 07 I8-2724. (http://www.jotmi.org)

Journal of Technology Management \& Innovation (c) Universidad Alberto Hurtado, Facultad de Economía y Negocios. 
and it is up to society to identify and take advantage of the opportunities provided by this medium.

Because the sports production sector is 'transversal', in that it embraces a variety of different areas of knowledge in order to meet the specific demands, whether in sports education, in competitive sport or in physical activities aimed at promoting health, the learning provided by the universities to society should include teaching, research and outreach that promotes university-industry-government interaction as a means of bringing about extensive regional impact that, in practical terms, can be considered the effective entrepreneurial legacy of such sporting events (Terra et al, 20l I).

In the USA and the wealthier countries of Europe, estimates of the average financial volume generated by the sports industry range between $2 \%$ and $3 \%$ of Gross Domestic Product (Proni, 2008). In the UK and the USA, for example, sport accounts for $4 \%$ to $5 \%$ of GDP, whereas in Brazil it was just I.9\% of GDP, or US\$ 4I billion, in 2010, (Graça and Kasznar, 20I2). This total embraces a broad range of factors, from the sale of sports items, events, sponsorship, promotion, patents and copyright in relation to brand licensing to investment in equipment, sporting arenas, services and wages. There is a growth possibility in this market, due to the expansion of the Brazilian economy and of the population's income level, on top of the boost for sporting activities that will occur from the upcoming mega-events.

According to data for 2010 , in the sporting goods market, the companies Nike, Adidas, Asics, Puma, Alpargatas, Reebok, Cambuci (Penalty), New Balance and Skechers, which together hold an $80 \%$ share of the market, generate annual revenues of around $R \$ 4.9$ billion and provide 62,000 direct and indirect jobs.

In view of the manufacturing costs, the leading companies in the sporting goods sector have chosen to produce most of their products in countries where labor is cheaper, such as Brazil, although the black market in such goods provides stern competition, particularly for licensed products (Dossiê Esporte 'Sports Dossier', 2007; apud Benazzi and Borges, 2009).

The lack of knowledge about the sport production chain raises a series of problems for Brazilian companies whose products and services are directly or indirectly linked to this segment, and it will be necessary to map out the present situation with as much precision as possible. From this map, it will be possible to see the extent of Brazilian ownership in this chain and thereby enable the setting up of knowledge transfer processes, through partnerships between Brazilian and foreign companies, backed by laws stimulating the national production of sports-related equipment and services (Alves, 2006).
According to Alves (2006), "the consumer of physical and sporting activities is the central figure in the entire growth process. It is $s /$ he that requires the public policies, the technological and methodological innovations in the academies, the improved equipment and installations at the sports clubs, the modernization and continual renewal of sportswear (clothing, shoes, etc.); and it is s/he who determines the size and content of the media coverage, publicity and advertising in relation to the sector. To this end, it is necessary to augment the local production of sports equipment and materials, to meet the increased demand for such items, in response to the growing practice of physical and sporting activities. This process can and should be accompanied by public policies providing incentives to Brazilian companies linked to this field".

Chias states that (2010), according to surveys in relation to the 2014 World Cup and taken into consideration in the Aquarela 2020 Plan by Marketing Turístico Internacional do Brasil, it is estimated that 500,000 foreign tourists will come to Brazil for the event. At the same time, Brazil will attract the strong interest of another 2 (two) billion plus people around the world. If we are able to inform them about the country and its innovative business potential, as well, of course, as its continental dimension and cultural and natural diversity, it will be possible to open up an international market for the production of Brazilian sporting goods and services.

Since the studies carried out in relation to the legacy of sporting mega-events include economic and technological angles, it was considered useful to conduct an assessment of the creation of academic spin offs incubated by Brazilian incubators, which would add interesting details to the existing studies, due to the specific Brazilian conditions mentioned above.

Consequently, the overall objective of this paper is to carry out an exploratory study into Brazilian academic spin offs, based on the triple helix model, which develops innovative products and services aimed at the sports market. More specifically, an effort has been made to map out the characteristics of the products and services of the spin offs in the sporting field that were studied, along with their sources of innovation, the financial resources received and the role of the universities and government in encouraging these innovations.

The work began with a preliminary survey, the results of which are presented herein, and the research is expected to continue over the next few years, in order to expand on the topic. The present paper is divided as follows: the first section contains the introduction; the second presents the current state-of-the-art in reference to this area; the third

ISSN: 07 I8-2724. (http://www.jotmi.org)

Journal of Technology Management \& Innovation (c) Universidad Alberto Hurtado, Facultad de Economía y Negocios. 
section presents the methodology utilized; the fourth section shows the analysis of the research results; and the fifth and last section contains the conclusions and recommendations for future public policies and research.

\section{State-of-the-Art}

The triple helix, which was also used as a point of reference for the methodology of this work, is a conceptual model that suggests there is a new dynamic in the relations between university, industry business and government and in the participation of each one in actions to foster innovation, using scientific research to generate new knowledge and technology (Etzkowitz and Leydesdorff, 1998).

University-business-government interaction was broadened with the introduction of a new concept, Triple Helix Spaces: Knowledge, Innovation and Consensus Spaces, which reveals the processes and mechanisms by which the institutional spheres interact and adapt over time in the striving for innovation, (Etzkowitz and Ranga, 2010).

The incubator is an example of the ideal interface structure for the activities of the triple helix players and is considered to be a hybrid organization that internalizes the relations between the three spheres, creating and fostering a space for interaction. The basic premise of the incubator is that the development of businesses can be improved by organizing it as an educational process. Within the triple helix model, the companies and cooperatives under incubation are seen as organizations that internalize the relationship between science, business and the state, stimulating the creation of an interactive space that connects those spheres (Etzkowitz, 2008).

According to Etzkowitz (2008), incubators in Brazil are considered to be an example of 'innovation spaces', which also generate organizational innovation practices. They perform functions related directly to economic and educational development and can also transform themselves into financing agents, which is traditionally an attribute of venture capital companies. One of the characteristics features of creating a space for innovation is that it encourages the presence of venture capital as a necessary source of investment in financial (entrepreneurial) undertakings needed to develop new products and services.

\section{Entrepreneurial University}

A review of the literature review about the environmental factors that affect the creation and development of the Entrepreneurial Universities, begins with the considerations of Etzkowitz, (1983) that: "Universities that are considering new sources of funding, such as like patents, research under by contracts and entry into a partnerships with a private enterprise".

According to Clark (1998), the entrepreneurial university is seen to be characteristic of a social system, not of a business viewpoint. This means that the institution accepted the idea of running risks when it initiated its new practices. An entrepreneurial university seeks to be innovative, pursuing tangible change in its organizational character, with a view to attaining a new position in the future. Hence, entrepreneurial universities seek to become "stand-up" universities that are significant players in their own right. Within this context, entrepreneurship is treated as a process, rather than being considered a result. In the view of this author, there are five fundamental features that the university must seek to develop in order to become an entrepreneurial university: a clear sense of the path that is to be followed, which is accepted by not only the central administration, but also by the academic departments; that its expansion incorporates society's demands and that the appropriate tools are created to promote these exchanges; its revenues must be diversified, so as to ensure its autonomy and sustainability; strengthening of its academic unites and an integrated entrepreneurial culture.

Etzkowitz et al (2000) called attention once again to the fact that, "... an 'entrepreneurial university' is a global phenomenon with an isomorphic developmental path, despite different starting points and modes of expression". In the triple helix model, the entrepreneurial university is an important player in the economic and social development of the region in which it is inserted (Etzkowitz et al, 2000).

\section{Spin off Firms}

There is ample definition of spin off firms within the literature.According to Steffensen et all (2000), a 'spin-off' venture is a firm that emerges from another organization. For these authors, a spin-off can be a planned or a spontaneously created business venture. The former is a firm that results from voluntary efforts by the initiating organization. The latter is a firm that results from the effort of the academic entrepreneur, who functions subject to with little or no encouragement by the organization which that creates the spin-off firm. Following Rappert et all (1999), an academic spin-off is defined as a firm with products or services developed from a technological idea or scientific/technical knowledge originated by a member of the university who that creates the spin-off firm. Shane (2004) defines an academic spin-off as a firm created to exploit IP intellectual property derived from a research activity developed at an academic institution.

According to Botelho and Almeida (2010), spin-off firms have received a boost from the introduction of the Inno-

ISSN: 07 I8-2724. (http://www.jotmi.org) 
vation Law, since it allows researchers to take leave from their academic activities in order to set up such a business. However, the fact that the universities still need to sort out their regulations in respect to the law and that knowledge of this legal mechanism has received limited dissemination mean that it is still a little used option.

\section{Participative Government}

Business needs the stimulus of efficient public policies to invest in innovation and thereby raise the competitiveness of Brazilian products in the local and international markets, as well as strengthening the respective production chains (Etzkowitz et al, 2000).

Terra (1999) affirms that the functions of a participative government are to stimulate the setting up of regional centers for S,T \& I organisms; structure the S,T \& I sector within a clear strategic vision; foster $\mathrm{S}, \mathrm{T}$ \& I infrastructure; provide partial support for the $\mathrm{S}, \mathrm{T}$ \& I infrastructure; legislate on intellectual property, patents, licensing and royalties; draw up specific regulations, incentives and subsidies for the $S$, $\mathrm{T}$ \& I sector; create standardization, normalization, quality control and assessment mechanisms; and develop public $\mathrm{S}$, $T$ \& I policies.

The elements of the public S,T \& I policies are defined by the participative government, within a holistic approach geared to the national, state and regional spheres, that involves: determining goals and priorities; defining the fields of action; defining the infrastructure that will be necessary to achieving the goals; determining the factors that will influence the achieving of the goals; defining the players; defining the participation strategies; defining the decision making mechanisms; defining the mechanisms for allocating the results; defining the penalty and protection mechanisms; and determining the means for evaluating and disclosing the results.

\section{Sport Based Entrepreneurship}

Besides In addition to the related above, according to Ratten, $(20 \mathrm{lla})$, given the context of that "sport-based entrepreneurship is a new theory of sport management", the major innovations during the past decade have been in the use of computer statistics to help with better improve team performance and the internationalization of the interest in sports leagues.

In the view of this author, sport-based entrepreneurship involves diverse factors, such as proactive behavior, innovation and risk. Consequently, the bridge between entrepreneurial studies and sport may be constructed from the perspective of sport-based entrepreneurship. Thus, the theoretical framework will facilitate an understanding of sports mar- keting, social entrepreneurship and technological innovation (Ratten, 20I lb).

The study into the segmentation of the sports industry, carried out by Pitts et al (1994), concluded, based on Porter's industry segmentation theory (Porter, 1985), that this sector is important to the identification of opportunities for setting up businesses and launching products and services, as well as for evaluating business strategies. Hence, they suggested that the sports industry be divided into three segments: sport performance, sport production and sport promotion. Moreover, in addition to these major segments, the authors noted that there are various categories of products and types of buyers. Their definitions of the three segments are as follows: I) sport performance segment - sport performance as offered to the consumer as a participation or spectatorial product; 2) sport production segment - those products needed or desired for the production of or to influence the quality of sport performance; 3) sport promotion segment: "those products offered as tools used to promote the sport product". This segmentation was used for classifying the companies studied in this paper, as shown in Table 2.

\section{Methodology}

The study identified some spin-offs, in different Brazilian incubators, that are working on sporting innovations in sport. Since no survey of this kind had previously been done, the first task was to research the websites of the incubators and companies under incubation, with a view to identifying those that have produced any products in this field. A total of 384 incubator websites were investigated, involving I,500 businesses. Of that total, it was seen that, in 136 incubators, there were 24 (twenty-four) businesses with products relating to the sports field. The survey took in the largest incubators in each state, and all regions of the country were investigated.

The survey sought to answer the following questions: I) What new research is being conducted into sports technology by spin off firms in Brazil? 2) How many and what sporting products are being developed? 3) What is the level of innovation of the products? 4) Does the product originate from a license on an academic patent, the result of a master's or doctoral thesis, a monograph, scientific initiation, or other source? 5) Was the R\&D developed in collaboration with the university? 6) What financial support was received by the company (government, venture capital, business angel)?

\section{Findings and interpretation}

This section shows the new research into sports technology that is being carried out by spin off firms in Brazil, how many and what sporting products are being developed and analy- 
sis of the following factors: types of products/services being offered; sources of knowledge for the development of the product/service; financial support received; and the role of the triple helix spheres (university - business - government) in generating innovation in this field. It also shows whether the items developed by the businesses that were studied originated from a master's or doctoral thesis, a monograph, scientific initiation, or other source. The financial support (government, venture capital, business angel) received by the firm, together with information on whether the product was developed under a license on an academic patent and whether the R\&D was carried out in collaboration with the university are all shown in Table I, below.

Innovations in the sporting field may involve organizational and technological factors. Organizational innovations may be related to sports teams (new strategies to increase enhance their performance); sports organizations (Professional sports leagues) and by sports players (Ratten, 20 I lb).

On the other hand, technological changes can lead to a variety of sporting innovations. For example, the advances in technology in terms of engineering and new materials have led to increase enhanced sporting achievements, as studied by Castonguay (2008) in the area of sports for the disabled sports; , the emergence of videogames and the development of videogames in the sporting field (Mullin et al, 2007), as well as innovations in equipment and technology.

Table I, below, shows the relationship between universities and research institutes, companies and incubators, as well as the financial support received and the sources of knowledge for the innovations.

ND - Information is not available.

CNPq - RHAE grant: The Program for the Preparation of Human Resources in Strategic Areas - RHAE, under the management of the Ministry of Science, Technology and Innovation - MCTI, with the work carried out by the CNPq (National Council for Scientific and Technological Development). The RHAE program uses a variety of different kinds of Technological Development grants, specially created to attract highly qualified individuals to perform R\&D activities in companies, as well as developing human resources for work on applied research or technological development projects. Criatec - BNDES:A seed capital Investment Fund for innovative new companies, which came about through a BNDES (Brazilian Development Bank).

FACEPE (Foundation in Support of Science and Technology in the State of Pernambuco) / FAPERJ (Carlos Chagas Filho Foundation in Support of Research in the State of Rio de Janeiro).
FAPESC - SINAPSE: FAPESC (Foundation in Support of Scientific and Technological Research in the State of Santa Catarina) and SEBRAE/SC (Brazilian Service for the Support of Small Enterprises in the State of Santa Catarina) launched the program "Sinapse da Inovação", which will provide around $R \$ 50,000$ each to up to 100 firms to develop innovative products or processes. The program was conceived with the intention of transforming and applying good ideas from students, researchers and professionals in different fields of knowledge. http://www.fapesc.sc.gov.br/ [Accessed April 20, 2012]

FAPESP-PIPE: FAPESP (Foundation in Support of Research in the State of São Paulo) launched the Program FAPESP - PIPE (Innovative Research in Small Enterprises) in 1997, which is aimed at supporting scientific and/or technological research in small enterprises based in the state of São Paulo. Research projects selected for support under the PIPE must be developed by researchers who have an employment link with a small enterprise or are associated with it for the purpose of the project. http://www.fapesp.br/ [Accessed April 20, 20I2]

FINEP - Economic Subsidies: The purpose of the FINEP (Funding Agency for Studies and Projects) Economic Subsidy is to promote a significant increase in innovative activities and enhance the competitiveness of the country's businesses and economy in general. This new financial support format allows public resources to be applied directly to companies on a non-reimbursable basis (they do not need to be repaid), thereby sharing the costs and risks inherent in such activities. The framework that allowed the granting of economic subsidies was established upon approval of Law no 10,973, of December 2, 2004, regulated by Decree no 5,563, of October II, 2005 (Innovation Law and regulations) [Brazil, 2004 and 2005] and Law no II, I 96, of November 2I, 2005, regulated by Decree no 5,798, of June 7, 2006 (LEI DO BEM Law and regulations) [Brazil, 2006]. This new scenario was created to promote innovation in the country's businesses and FINEP, a public entity linked to the Ministry of Science and Technology, is its principal agent. http://www.finep.gov. br/programas/subvencao_economica.asp[Accessed April 20, 20I2]

FINEP - PRIME: The Primeira Empresa Inovadora - PRIME program was launched by FINEP at the beginning of 2009. The objective is to create favorable financial conditions for a significant number of high added value start-ups to be able to successfully consolidate the initial phase of the development of their enterprise. http://www.finep.gov.br/programas/prime.asp [Accessed April 20, 20I2]

SEBRAETEC: The program SEBRAETEC is an instrument of the SEBRAE System that allows firms access to existing technological know-how within the S,T \& I infrastructure,

ISSN: 07 I8-2724. (http://www.jotmi.org)

Journal of Technology Management \& Innovation (c) Universidad Alberto Hurtado, Facultad de Economía y Negocios. 
Table I - The role of universities, government and spin-off firms in innovation. Source: the authors.

\begin{tabular}{|c|c|c|c|c|c|c|c|}
\hline University & Incubator & $\begin{array}{l}\text { Spin-off } \\
\text { Firms }\end{array}$ & Founded & $\begin{array}{l}\text { Government } \\
\text { support }\end{array}$ & $\begin{array}{l}\text { Business } \\
\text { Angel } \\
\text { support }\end{array}$ & $\begin{array}{l}\text { Venture } \\
\text { Capital } \\
\text { support }\end{array}$ & Source of knowledge \\
\hline $\begin{array}{l}\text { Federal Uni- } \\
\text { versity of Ita- } \\
\text { jubá-UNIFEI }\end{array}$ & $\begin{array}{l}\text { Incubator of Tech- } \\
\text { nology-Based } \\
\text { Companies-INCIT/ } \\
\text { Itajubá,MG }\end{array}$ & Tirante A & 2004 & $\begin{array}{l}\text { FAPESP- } \\
\text { PIPE, FINEP } \\
\text { - Subvenção } \\
\text { Econômica, } \\
\text { CNPq - RHAE } \\
\text { Scholarship. } \\
\end{array}$ & Yes & - & - \\
\hline \multirow{3}{*}{$\begin{array}{l}\text { Federal Uni- } \\
\text { versity of Rio } \\
\text { de Janeiro - } \\
\text { UFRJ }\end{array}$} & \multirow{3}{*}{$\begin{array}{l}\text { Incubator of Tech- } \\
\text { nological Based } \\
\text { Companies of } \\
\text { COPPE/Rio de } \\
\text { Janeiro, RJ }\end{array}$} & $\begin{array}{l}\text { Control- } \\
\text { lato }\end{array}$ & 2005 & - & - & - & PhD Thesis. \\
\hline & & ARAM & 2005 & FAPERJ & - & - & $\begin{array}{l}\text { Final graduation project and } \\
\text { R\&D in collaboration with the } \\
\text { university. }\end{array}$ \\
\hline & & $\begin{array}{l}\text { Holos } \\
\text { Brasil }\end{array}$ & 1998 & FAPERJ & Yes & - & Scientific Initiation Program. \\
\hline $\begin{array}{l}\text { State Universi- } \\
\text { ty of Campinas } \\
\text { - UNICAMP }\end{array}$ & $\begin{array}{l}\text { Company for the } \\
\text { Development of } \\
\text { the Campinas High } \\
\text { tech Hub/CIETEC } \\
\text { Campinas, SP }\end{array}$ & $\begin{array}{l}\text { Match } \\
\text { Report }\end{array}$ & 2000 & FAPESP-PIPE & - & - & - \\
\hline $\begin{array}{l}\text { Federal Uni- } \\
\text { versity of } \\
\text { Minas Gerais } \\
\text {-UFMG }\end{array}$ & $\begin{array}{l}\text { Habitare Incubator, } \\
\text { Fundação Biom- } \\
\text { inas Foundation, } \\
\text { Belo Horizonte, MG } \\
\end{array}$ & EDETEC & 2006 & $\begin{array}{l}\text { FINEP - } \\
\text { Subvenção } \\
\text { Econômica }\end{array}$ & - & $\begin{array}{l}\text { Criatec - } \\
\text { BNDES }\end{array}$ & $\begin{array}{l}\text { Patent license from the uni- } \\
\text { versity. }\end{array}$ \\
\hline $\begin{array}{l}\text { University of } \\
\text { São Paulo - } \\
\text { USP }\end{array}$ & $\begin{array}{l}\text { Center for Inno- } \\
\text { vation, Enterprise } \\
\text { and Technology - } \\
\text { Cietec/São Paulo, } \\
\text { SP }\end{array}$ & Initec & 2010 & - & - & - & - \\
\hline \multirow{2}{*}{$\begin{array}{l}\text { Federal } \\
\text { University } \\
\text { of Paraíba - } \\
\text { UFPB }\end{array}$} & $\begin{array}{l}\text { Technology Park } \\
\text { Foundation of } \\
\text { Paraíba - Paqtec/ } \\
\text { Campina Grande, } \\
\text { PB }\end{array}$ & $\begin{array}{l}\text { Quatro } \\
\text { Bordas }\end{array}$ & 2008 & FINEP -PRIME & - & - & - \\
\hline & $\begin{array}{l}\text { Technology Park } \\
\text { Foundation of } \\
\text { Paraíba - Paqtec/ } \\
\text { Campina Grande, } \\
\text { PB }\end{array}$ & $\begin{array}{l}\text { Tech } \\
\text { Coach }\end{array}$ & ND & FINEP - PRIME & - & - & - \\
\hline $\begin{array}{l}\text { Paraná In- } \\
\text { stitute of } \\
\text { Technology - } \\
\text { TECPAR }\end{array}$ & $\begin{array}{l}\text { Technological In- } \\
\text { cubator- INTEC/ } \\
\text { Curitiba, PR }\end{array}$ & BioSmart & 2006 & $\begin{array}{l}\text { FINEP - } \\
\text { Subvenção } \\
\text { econômica, } \\
\text { CNPq - Bolsa } \\
\text { RHAE }\end{array}$ & Yes & - & Master dissertation. \\
\hline $\begin{array}{l}\text { Santa Cecília } \\
\text { University- } \\
\text { UNISANTA }\end{array}$ & $\begin{array}{l}\text { Business Incubator } \\
\text { of Santos/Santos, } \\
\text { SP }\end{array}$ & IT \& D & 2004 & $\begin{array}{l}\text { FAPESP-PIPE, } \\
\text { FINEP - } \\
\text { Subvenção } \\
\text { Econômica, } \\
\text { SEBRAETEC }\end{array}$ & Yes & Yes & Scientific Initiation Program. \\
\hline
\end{tabular}

ISSN: 07 I8-2724. (http://www.jotmi.org) 


\begin{tabular}{|c|c|c|c|c|c|c|c|}
\hline \multirow{5}{*}{$\begin{array}{l}\text { Federal Uni- } \\
\text { versity of } \\
\text { Pernambuco } \\
\text { - UFPE }\end{array}$} & $\begin{array}{l}\text { Center for En- } \\
\text { terprise in Sci- } \\
\text { ence,Technology } \\
\text { and Art - NECTAR/ } \\
\text { Recife, PE }\end{array}$ & FiTfam & ND & FINEP - PRIME & - & - & - \\
\hline & \multirow{4}{*}{$\begin{array}{l}\text { Center for Ad- } \\
\text { vanced Studies } \\
\text { and Systems of } \\
\text { Recife - CESAR/ } \\
\text { Recife, PE }\end{array}$} & $\begin{array}{l}\text { Finger } \\
\text { Tips }\end{array}$ & - & - & - & - & - \\
\hline & & Sophia & 2006 & $\begin{array}{l}\text { FINEP - } \\
\text { Subvenção } \\
\text { econômica }\end{array}$ & - & - & - \\
\hline & & \begin{tabular}{|l} 
Jynx \\
Playwere
\end{tabular} & 2000 & - & & & $\begin{array}{l}\text { Project under the Undergradu- } \\
\text { ation Entrepreneurship Course }\end{array}$ \\
\hline & & $\begin{array}{l}\text { Mean- } \\
\text { time }\end{array}$ & 2003 & $\begin{array}{l}\text { CNPq - Bol- } \\
\text { sa RHAE, } \\
\text { FACEPE, } \\
\text { FINEP - } \\
\text { Subvenção } \\
\text { Econômica }\end{array}$ & - & CESAR & - \\
\hline $\begin{array}{l}\text { Federal Uni- } \\
\text { versity of São } \\
\text { Carlos - UFS- } \\
\text { CAR }\end{array}$ & $\begin{array}{l}\text { São Carlos } \\
\text { Technology Park } \\
\text { Foundation Center } \\
\text { for the Incubation } \\
\text { of Technology - } \\
\text { Based Companies } \\
\text { - CINET -ParqTec, } \\
\text { São Carlos, SP }\end{array}$ & XВOT & 2007 & $\begin{array}{l}\text { SEBRAETEC, } \\
\text { FAPESP - PIPE, } \\
\text { CNPq -Bolsa } \\
\text { RHAE, FINEP- } \\
\text { Subvenção } \\
\text { Econômica }\end{array}$ & Yes & - & Post Doctoral Research. \\
\hline $\begin{array}{l}\text { Federal Uni- } \\
\text { versity of Viço- } \\
\text { sa - UFV }\end{array}$ & $\begin{array}{l}\text { Incubator of Tech- } \\
\text { nology - Based } \\
\text { Companies /Viço- } \\
\text { sa, MG }\end{array}$ & $\begin{array}{l}\text { Esporte } \\
\text { Sistemas }\end{array}$ & 2008 & FINEP - PRIME & - & - & $\begin{array}{l}\text { Business plan, drawn up along } \\
\text { with the UFMG Computer Sci- } \\
\text { ence Department's Center for } \\
\text { Enterprise and Innovation, won } \\
\text { first place in a competition or- } \\
\text { ganized by the State Science, } \\
\text { Technology and Higher Edu- } \\
\text { cation Department - SECTES, } \\
\text { MG. }\end{array}$ \\
\hline $\begin{array}{l}\text { Veiga de } \\
\text { Almeida Uni- } \\
\text { versity - UVA } \\
\end{array}$ & $\begin{array}{l}\text { UVA Business } \\
\text { Incubator/Rio de } \\
\text { Janeiro, RJ } \\
\end{array}$ & $\begin{array}{l}\text { Rio Ral- } \\
\text { ly's }\end{array}$ & 2008 & - & - & - & - \\
\hline $\begin{array}{l}\text { University } \\
\text { of Southern } \\
\text { Santa Catarina } \\
\text { - UNISUL }\end{array}$ & $\begin{array}{l}\text { Unisul Regional } \\
\text { Center for Innova- } \\
\text { tion and Enterprise } \\
\text { - CRIE/Tubarão, } \\
\text { SC } \\
\end{array}$ & EPT Web & 2009 & $\begin{array}{l}\text { FINEP- PRIME } \\
\text { e FAPESC - } \\
\text { SINAPSE }\end{array}$ & - & - & $\begin{array}{l}\text { Final course project for ob- } \\
\text { taining a degree in Computer } \\
\text { Science. }\end{array}$ \\
\hline $\begin{array}{l}\text { State Universi- } \\
\text { ty of Northern } \\
\text { Fluminense - } \\
\text { UENF }\end{array}$ & $\begin{array}{l}\text { Campos Incubator } \\
\text { of Technology - } \\
\text { Based Companies } \\
\text { - TEC-CAMPOS/ } \\
\text { Campos, RJ }\end{array}$ & $\begin{array}{l}\text { FITNESS } \\
\text { Clínica }\end{array}$ & ND & - & - & - & - \\
\hline $\begin{array}{l}\text { Federal Uni- } \\
\text { versity of } \\
\text { Ceará - UFC }\end{array}$ & $\begin{array}{l}\text { Technological } \\
\text { Development Park } \\
\text { - Padetec/Fortale- } \\
\text { za, CE }\end{array}$ & Nutrimax & 2004 & - & - & - & - \\
\hline $\begin{array}{l}\text { Catholic Uni- } \\
\text { versity of Rio } \\
\text { Grande do Sul } \\
\text { - PUCRS }\end{array}$ & $\begin{array}{l}\text { PUCRS Scientific } \\
\text { and Technological } \\
\text { Park - TECNOPUC }\end{array}$ & $\begin{array}{l}\text { Engeltec } \\
\text { Soluções } \\
\text { Digitais }\end{array}$ & 2006 & - & - & - & - \\
\hline $\begin{array}{l}\text { Orsa Founda- } \\
\text { tion }\end{array}$ & $\begin{array}{l}\text { Vale do Jari Incu- } \\
\text { bator of Solidarity } \\
\text { and Sustainable } \\
\text { Eco-businesses, } \\
\text { Monte Dourado, PA }\end{array}$ & $\begin{array}{l}\text { Atleta } \\
\text { Solidário }\end{array}$ & 2009 & - & - & - & - \\
\hline
\end{tabular}

ISSN: 07 I8-2724. (http://www.jotmi.org) Journal of Technology Management \& Innovation (c) Universidad Alberto Hurtado, Facultad de Economía y Negocios. 
with a view to improving the processes and products and/ or introducing innovations in companies or in the market.http://portal.pr.sebrae.com.br/sebraetec/Conteudo. do? $\operatorname{codConteudo}=0$ [Accessed April 20, 2012]

A visual representation of the interaction between university - business - government in the creation of spin offs whose products and/or services include those dedicated to opportunities in the sporting field can be seen in Figure I, below.

The companies need the incentives provided by efficient public policies to be able to invest in innovation and thereby raise the competitiveness of Brazilian products in both local and international markets, as well as strengthening the respective production chains (Kolt, 20I I).

The elements of the public policies for S, T \& I will be defined by the participative government, as part of a holistic approach geared to the national, state and regional spheres, and involves: determining the goals and priorities; defining the fields of action; defining the infrastructure that will be necessary to achieving the goals; determining the factors that will influence the achieving of the goals; defining the players; defining the participative strategies; defining the decision making mechanisms; defining the mechanisms for allocating the results; defining the penalty and protection mechanisms; and determining the means for evaluating and disclosing the results. A perfect example of the role of the government in the development of research that generates innovations in the sporting field and in supporting start-ups in this field is the activities of FINEP. A FINEP has invested around $\mathrm{R} \$ 10$ million over the last three years in research in the sporting field in 2007, (under the financial grants program) and launched the 2014 BIS Program in October 2010, with a view to supporting initiatives linked to the Soccer football World Cup and Summer Olympic Games that Brazil will be hosting. According to FINEP (2010): "This is an opportunity and an incentive to develop Science \& Technology, so that the country can finally become a player in this field, and not merely a buyer of sporting events and solutions", in the words of Ricardo Avellar, general coordinator of Sporting Excellence at the National Department for Competitive Sports, in Brazil.

According to FINEP (2010): "This is an opportunity and an incentive to develop Science \& Technology, so that the country can finally become a player in this field, and not merely a buyer of sporting events and solutions", in the words of Ricardo Avellar, general coordinator of Sporting Excellence at the National Department for Competitive Sports, in Brazil.

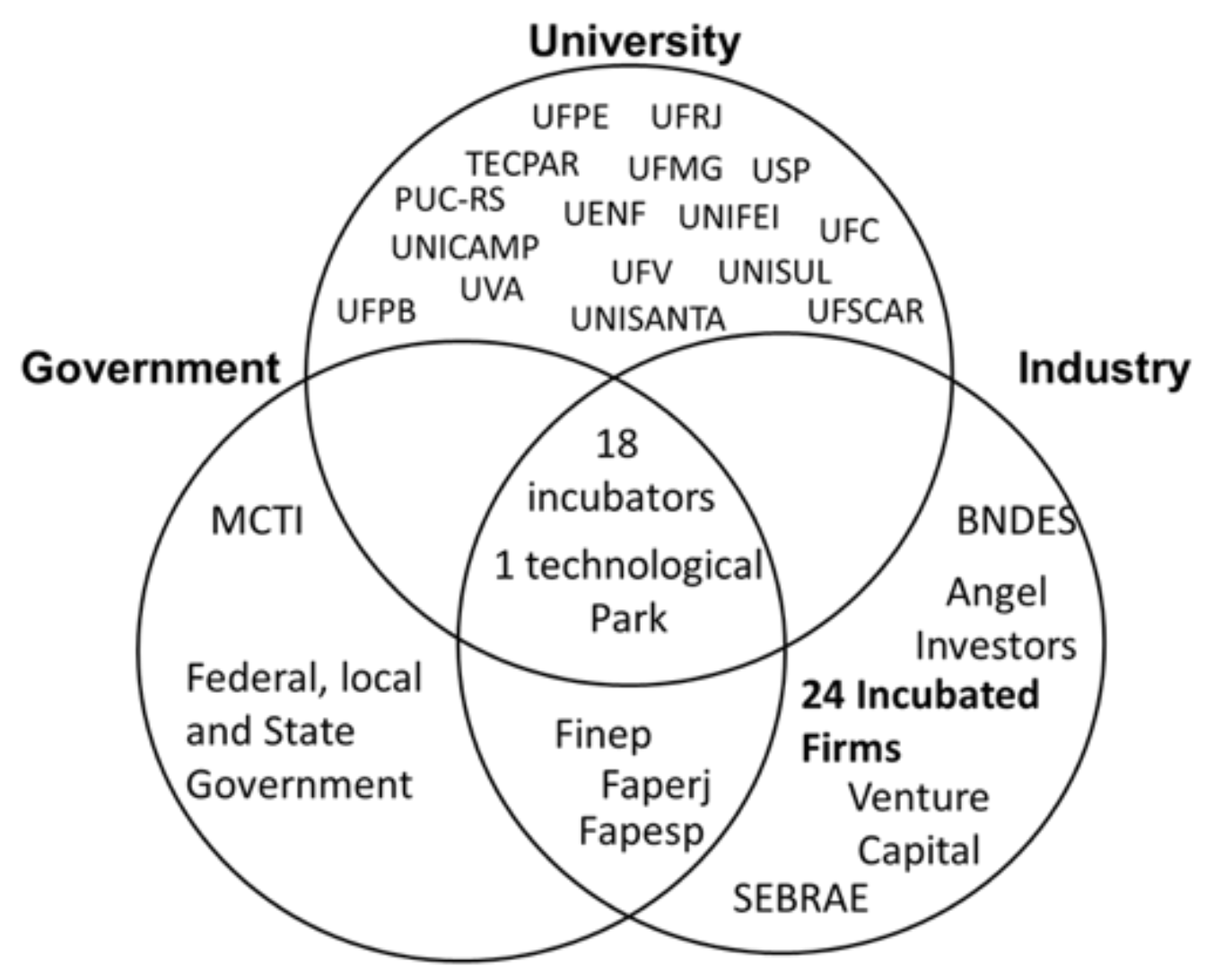

Figure I:Triple Helix in Sports in for Spin Off firms in Brazil. Source: the authors.

ISSN: 07 I8-2724. (http://www.jotmi.org)

Journal of Technology Management \& Innovation (c) Universidad Alberto Hurtado, Facultad de Economía y Negocios. 
In 2010, FAPERJ launched the program "Support for the Development of Sporting Innovations in the State of Rio de Janeiro - 2010". The call for tenders was aimed at universities, businesses and independent inventors, with the objective of supporting scientific and/or technological projects that innovate in the preparation of athletes, training of coaches or development of sports-related equipment, for the purpose of helping to spread the practicing of sports; introducing quality in the practicing of sports; training and updating of the techniques and knowledge of sports coaches; improving the infrastructure needed for the practicing of sports; and developing equipment and technological solutions, all in the state of Rio de Janeiro, (FAPERJ, 20I I). One of the firms that received this support is Holos, a previously above men- tioned spin-off for the task of building a carbon fiber mast for the Finn racing class of yachts.

In addition to the specific programs mentioned above, the information collected from the companies under incubation leads to the conclusion that other, non-reimbursable sources of funding provided by FINEP (Economic subsidies and PRIME) and state agencies (FAPESP, FACEPE) have been used by the firms to obtain resources for innovation.

The Brazilian spin-offs identified in this research of the websites of the incubators and in interviews develop a variety of products/services in the sporting field. The diversity of these products/services shows the different opportunities that

\begin{tabular}{|c|c|c|}
\hline $\begin{array}{l}\text { Sport Industry Segment } \\
\text { (Pitts et all. (1994), }\end{array}$ & Enterprise & Equipment/Service \\
\hline \multirow{17}{*}{$\begin{array}{l}\text { Sport production } \\
(71 \%)\end{array}$} & Initec & equipment: mouth protector for sports competitions \\
\hline & Tirante A & $\begin{array}{l}\text { equipment: flight instrument that can be used in gliding, paragliding and hang glid- } \\
\text { ing }\end{array}$ \\
\hline & Holos Brasil & equipment: sailing boat class \\
\hline & ARAM & sport facility: tecnologia para criar artificialmente ondas ideais à prática do surfe \\
\hline & Controllato & sport facility: the measure of the fans' impact on the stadium's concrete structure \\
\hline & BioSmart & medical care: advanced rehabilitation systems \\
\hline & EDETEC & medical care: products for clinical and sports nutrition, used by the food industry \\
\hline & Nutrimax & medical care: nutritional supplements \\
\hline & Quatro Bordas & $\begin{array}{l}\text { performance production: performance production: system of evaluation for com- } \\
\text { petitive sports, notably swimming }\end{array}$ \\
\hline & Esporte Sistemas & performance production: system of physical evaluation and sports prescription \\
\hline & IT \& D & performance production: system for measuring speed in real time, for swimmers \\
\hline & Tech Coach & $\begin{array}{l}\text { performance production: products for assessment and training, in real time, of on- } \\
\text { field movement and the performing of tactical moves, for football players }\end{array}$ \\
\hline & Match Report & performance production: software for "scout" \\
\hline & EPT Web & performance production: system of physical/nutritional evaluation and prescription \\
\hline & FitFam & $\begin{array}{l}\text { fitness trainer: physical training in companies, including sporting events, calisthen- } \\
\text { ics and physiotherapy }\end{array}$ \\
\hline & FITNESS Clinica & fitness trainer: sporting advice \\
\hline & Atleta Solidário & $\begin{array}{l}\text { fitness trainer: promoting social inclusion through sport, for people with visual, in- } \\
\text { tellectual, physical, hearing or multiple disabilities sport performance }\end{array}$ \\
\hline \multirow[t]{2}{*}{ Sport performance } & $\begin{array}{l}\text { Engeltec Soluções } \\
\text { Digitais }\end{array}$ & $\begin{array}{l}\text { sport spectating: producing customized electronic gadgets for use in a variety } \\
\text { of corporate environments, including the sale and control of tickets for events and } \\
\text { shows }\end{array}$ \\
\hline & Sophia & $\begin{array}{l}\text { sport spectating: a 'virtual' narrator of football games, via mobile phone sport } \\
\text { promotion }\end{array}$ \\
\hline \multirow{5}{*}{ Sport promotion } & FingerTips & tool: smartphone apps for the sporting field \\
\hline & JynxPlayware & tool: sports games for mobile and smartphones \\
\hline & Meantime & tool: sports games for mobile and smartphones \\
\hline & XBOT & tool: games - Rogobol, using robotics \\
\hline & Rio Rally's & tool: events, like tourism, cultural, historical, ecological and adventure circuits \\
\hline
\end{tabular}

Table 2 - Spin offs in the sporting field. Source: the authors.

ISSN: 07 I8-2724. (http://www.jotmi.org)

Journal of Technology Management \& Innovation (C) Universidad Alberto Hurtado, Facultad de Economía y Negocios. 
have been identified in the industry devoted to the sporting field in Brazil. These products/services are shown in Table 2, below, using the sports industry segmentation developed by Pitts et al (1994).

Of the 24 companies, one can see that 17 , equivalent to $71 \%$ of the total, are active in the Sport production segment, which may be sub-divided into the following product categories: I) out fitting products: equipment and apparel; and 2) performance production products: fitness trainer, medical care, sports facilities and governing bodies. In the sport production segment, outfitting products category, it can be seen that three companies are dedicated to producing equipment. Two of these companies develop equipment for sporting segments that are of more limited public access in Brazil: gliding and sailing. This choice may be partially explained as taking advantage of opportunities in market niches, since, as mentioned previously, the major international companies have an $80 \%$ share of the Brazilian market for traditional sporting goods, making it hard for new companies to penetrate this sector, particularly when they are small ones.

Meanwhile, the firm Holos Brasil appeared in 1998, as a result of the enthusiasm of two young students in the UFRJ's Marine Engineering Program, who were motivated by their experience in the Scientific Initiation Program, where they had built a wooden snipe class sailing boat for the Snipe class, one of the Pan-American Games' yacht racing categories. The same year the company was set up also saw the emergence of the UFRJ nautical center, a Marine Engineering Department initiative, with which the company has a close partnership. The first project was finalized in 2002: the Double Canoe, a rowboat for two people. Then, in 2004 was a big growth year for the dinghy project, which enabled the financing of an even more ambitious project: the Emi, a 4.7 meter yacht.After nearly two years of research, planning and development, and testing and adjustments on a prototype, the production molds were finalized and a new Brazilian sailing boat class was publicly launched in 2006.

Another example is Tirante A, a firm hosted by the INCIT, as a tool for the UNIFEl entrepreneurship program from UNIFEI, which was set up in 2004 and comprises pilots and electronics engineers with years of experience in electronics projects, who are trying to provide for the needs of those practicing unpowered flight. The first product launched by Tirante A was the TAV-1000, a flight instrument that can be used in gliding, paragliding and hang gliding. The first instrument of its kind to be developed and manufactured in Brazil, the TAV- 1000 helps to identify air currents and provides the pilot with data regarding altitude, take off, temperature and flight duration. The success of this product, which took three years to develop, has encouraged the entrepreneurs to work on new products. The next model, the TAV-1500, which is in the process of development, is a new digital variometer with specific functions for competitions. The company's aim is to augment production, consolidate its position in the Brazilian market and pave the way for exports. Having completed its incubation period, the company established itself in the São José dos Campos technological park, in the state of São Paulo, which is a major hub for ecotourism and technological development in Brazil.

The third company in this category is developing a product that is intended to offer superior quality to the local brands, yet at a lower price than the imported equivalents. Once Initec, incubated at USP's Cietec, had demonstrated the possibility of developing local products that were more economically accessible, this stimulated other companies to also create new products in this field.

Remaining with the Sport production segment, outfitting products category, it was noted that, of the 14 companies classified under performance production, six of them develop fitness trainer products/services and three in medical care, while another two provide services in the sports facilities field.

The fitness trainer companies are dedicated to strength and conditioning coaching and carry out activities in the coordination of athlete's' fitness, conditioning, and the sport training program. Analysis of the products/services offered by these companies shows that six of them are active in the sector of sports performance segment, for the purpose of analyzing and evaluating information in key areas related to improved athletic performance.

Match Report develops software for "scouts", which analyzes the moves during football matches, for the purpose of identifying the tactics employed by opposing teams. The company appeared in 2000 , founded by economics and computer engineering students at UNICAMP and computer engineering students at the Catholic University of Campinas - PUC/Campinas, and is under incubation at UNICAMP's CIATEC, from UNICAMP.

The other three companies studied provide sports instruction and training services. Notable among them is the Athlete Solidarity Program of the Orsa Group's Vale do Jari Incubator of Supportive and Sustainable Eco-businesses, which promotes social inclusion through sport, for people with visual, intellectual, physical, hearing and multiple deficiencies. Of the medical care companies, two of them produce nutritional supplements for athletes, while the other operates in the field of rehabilitation. One of the nutritional supplement companies is Edetec, of the Biominas Foundation's Habitare Incubator, whose product arose from technology transferred from UFMG and the quest for a product developed in 
Brazil that would offer improved characteristics in relation to the imported product.

BioSmart, operating in the field of rehabilitation, is under incubation at TECPAR's INTEC. The company came about as a result of the widespread acceptance and recognition within the scientific community of Leonardo Rodrigues da Silva's master's thesis. Having presented his research results at a European congress on rehabilitation, he was encouraged by other researchers in the fields of Biomedical Engineering and Rehabilitation Engineering to launch a product developed from the results of his investigations.

Some spin-offs developed work for the 2007 Pan-American Games in Rio. One example is Controllato, created in 2005 with the participation of the COPPE incubator from at the UFRJ. This company originated at in the civil engineering program's Structural Laboratory and it is the fruit of a partnership between one of the professors and a student studying for a doctorate. The company has conducted a study on behalf of the consortium responsible for renovating the Maracanã stadium, in the city of Rio de Janeiro city. The aim of the study was to assess the fans' impact on the stadium's concrete structure. To avoid problems arising from the fans' exuberant celebrations, the company installed multiple synchronized dynamic attenuators, which absorb the energy released by the fans.

There are five companies in the sport promotion segment. One of these is a company that organizes sporting events, while the other four stimulate the practicing of sports through the development of applications for smartphones that simulate games. Just as new technology, such as sport video games, has introduced innovations in the field of sport, sport video games have become the third most popular type of video game (Mullin et al, 2007). And innovations arising from the development of smartphones and mobile telephony have provided incentives for the creation of products for this sub-sector. The possibilities for exploring this market, both in Brazil, with the expansion of the mobile telephony, and abroad will enable the accumulated knowledge and capacity in the software production field to be used to create products for the sporting field, as in the case of the firms Jynx Playware and Finger Tips.

With regard to the analysis of the level of innovation in the products/services, this was done according to OECD concepts (1997). It was seen that there was no product that was completely innovative, in global terms, but that they could be considered as innovative from the point of view of Brazil. It is believed that this is the reason why 15 (fifteen) of the twenty-four companies studied have received financial support from government agencies for the development of innovations.
This is similar to the results of the Technological Innovation Survey 2008 - PINTEC, carried out by the IBGE (Brazilian Institute of Geography and Statistics) for the purpose of analyzing the technological innovation activities of Brazilian companies. That survey showed that, of a total of 106,800 companies, around 41,300 , equivalent to $38.65 \%$, introduced a new or substantially improved product and/or process between 2006 and 2008. However, it was ascertained that $32.10 \%$ informed that their innovation was in progress, with the acquisition of machinery and equipment still taking place (IBGE/PINTEC, 2008). The rate of innovation of new products in the Brazilian market is $4.10 \%$, while the rate of innovation of new processes in the domestic market is $2.32 \%$ (IPEA, 20I I). So, although the spin-off firms developing innovative products and services for the country may be included amongst the limited number of innovative Brazilian companies, it can be seen that they have been unable to alter the national scenario revealed in previous surveys.

\section{Conclusion: policy implications and directions for further research into sports entrepreneurship in Brazil}

The expansion of business in the sporting field shows that there are many opportunities in this area for entrepreneurs. The winners in this market are technology-based companies with innovative ideas. The president of the Brazilian Olympic Committee - COB, Carlos Arthur Nuzman, has observed that, "With each Olympic cycle we can see that sport and technological innovation are increasingly inter-related" (Horn, 2007).

Although sport in Brazil has been studied in relation to a variety of different areas, including: Physical Education, Management, Health, Physiotherapy, Marketing, Sociology, Philosophy and Psychology, there is still a gap in regard to innovation and entrepreneurship aimed at business opportunities, which we are attempting to address in this paper, through the analysis of academic spin-offs.

The research results indicate that the universities were the sources of knowledge for some of the firms to develop their products or business model. Furthermore, it was ascertained that the vast majority of the firms obtained non-reimbursable resources or grants in support of their research, in order to be able to develop their products. In this role, the structures set up by the universities - the incubators - collaborated towards this end, with both management support and in the consolidation of the undertaking, which, effectively, increased the firms' chances of success.

Within the sporting economic sphere one should also consider other sports that do not feature in the Olympic scenario, yet offer a fertile environment for the development of innovative business ideas. 
We trust that this paper has contributed towards progress in the scenario considered herein, by presenting an analysis of the creation of new enterprises based on products and services developed by academic spin offs that are part of the incubation programs supported by universities.

It is hoped that the results of this analysis help to highlight the potential of this association in promoting the development of projects through this partnership, as well as in more extensive analysis of the technological capacity for innovation and market opportunities to guide the creation of new products.

\section{References}

ALVES, J. A. B. (2006). Cenário de Tendências Econômicas dos Esportes e Atividades Físicas no Brasil. In: L. DaCosta, L. (Eds.). Atlas do Esporte no Brasil. Conselho Federal de Educação Física - CONFEF. Rio de Janeiro. pp. 35-36.

ANPROTEC.Associação Nacional de Entidades Promotoras de Empreendimentos Inovadores. (2004). Panorama. http:// www.anprotec.org.br/ArquivosDin/panorama_final_pdf_09. pdf [Accessed April 4, 20I2]

ANPROTEC.Associação Nacional de Entidades Promotoras de Empreendimentos Inovadores. (2012). Um novo Retrato. Revista Locus, Ano XVII (65), 46-47.

BENAZZI,J.R. S. C., Borges, C. N. (2009). Emoção, Exposição e Vendas: análise do patrocínio realizado por marcas de artigos esportivos no futebol brasileiro. In:VI Simpósio de Excelência em Gestão e Tecnologia, 2009, Resende. Anais do VI Simpósio de Excelência em Gestão e Tecnologia - SEGET. Resende: Associação Educacional Dom Bosco. http://ww.aedb. br/seget/artigos09/147_Marketing\%20no\%20esporte\%20 final\%20com\%20autores.pdf [Accessed March 03, 20I2]

BOTELHO, A. J. J., Almeida, M. (2010). Overcoming institutional shortcomings for academic spin-off policies in Brazil. International Journal of Technology Management \& Sustainable Development, 9(3), 175-193.

CASTONGUAY, S., Jewell, C. (2008).Technology, innovation and grit: Faster, higher, stronger in disabled sports. WIPO Magazine, N. 4, 3-5.

CHIAS, J. (20I0). Brasil 20।4: uma visão a partir do marketing e do turismo. (2010). http://www.gramado.onde.ir/component/content/article/8-variadas/I 50 I-brasil-20 I4-umavisao-a-partir-do-marketing-e-do-turismo [Accessed on March 9, 2010]
CLARK, B. R. (1998). Creating Entrepreneurial Universities: Organizational Pathways of Transformation (Issues in Higher Education), vol. I2. (First ed.). Pergamon Press, London.

DACOSTA, L. P., Correa, D., Rizzut, E., Villano, B. (editors). (2008). Legados de Mega eventos esportivos. (First ed.). Ministério dos Esportes. Brasília.

ETZKOWITZ, H. (1983). Entrepreneurial Scientists and Entrepreneurial Universities in American Academic Science. Minerva, 2 I (2-3), 198-233.

ETZKOWITZ, H. (2008). The Triple Helix: university-industry-government, Innovation in Action. (First ed.). Routledge. New York, London.

ETZKOWITZ, H., Mello, J., Almeida, M. (2005). Towards "meta-innovation" in Brazil: the evolution of the incubator and the emergence of a triple helix, Research Policy, 34(4), 4I I424.

ETZKOWITZ, H., Webster, A., Gebhardt, C., Terra, B. (2000). The future of the university and the university of the future: evolution of ivory tower to entrepreneurial paradigm. Research Policy, 29(2), 3।3-330.

ETZKOWITZ, H.; Leydesdorff, L. (I998).The endless transition:A "triple helix" of university- industry-government relations. Minerva, 36(3): 203-208.

ETZKOWITZ, H., Ranga M. (20I0).A Triple Helix System for Knowledge-based Regional Development: From "Spheres" to "Spaces". Theme paper for Triple Helix 8 International Conference, Madrid, October 2010. http://www.triplehelix8. org/downloads/Theme-Paper.pdf [Accessed September 25, 20I0]

FINEP, Financiadora de Estudos e Projetos. (2010). De olho no pódio, Brasil investe em tecnologias esportivas. Revista Inovação em Pauta - Capa: Esportes, Número 8.

GRAÇA,A., Kasznar, I. (20I2).A indústria do esporte no Brasil, Economia, PIB, Emprego e Evolução Dinâmica. Edita M Books: São Paulo.

HORN, D. (2007). Corrida pela inovação. Locus - Ambiente da inovação brasileira, $N^{\circ} 49$, Ano XIII.

IBGE. Instituto Brasileiro de Geografia e Estatística. (2008). Pesquisa de Inovação Tecnológica - PINTEC. IBGE: Brasília.

IPEA. Instituto de Pesquisa Econômica e Aplicada. (20II). Trajetória Recente dos Indicadores de Inovação no Brasil. Textos para Discussão n 1659. IPEA: Brasília. 
KOLT, G. S. (20II). Editorial Innovation and translation in sports medicine and sports science research. Journal of Science and Medicine in Sport, I4(2), 93-94.

MULLIN, B., Hardy, J.,Sutton, W. (2007). Sport marketing. (3rd ed.). Human Kinetics. Champaign.

OECD. Organization for Economic Co-operation and Development. (1997). Oslo Manual. http://www.oecd.org/dataoecd/35/6I/2367580.pdf [Accessed January 10, 20I2]

PITTS, B., Fielding, L., Miller, L. (1994). Industry segmentation theory and the sport industry: developing a sport industry segment model. Sport Marketing Quarterly [SMQ], 3(I), I5 -24 .

PORTER, M. E. ( 1985$)$. Competitive Advantage: creating and sustaining superior performance. (First ed.) The Free Press. New York.

PRONI, M.W. (2008). Economia do esporte: um campo de estudo em expansão. $1^{\circ}$ Encontro da ALESDE: Esporte na América Latina: atualidade e perspectivas, UFPR - Curitiba Paraná - Brasil 30, 31/10 e 01// I/2008. Available on: http:// www.alesde.ufpr.br/encontro/trabalhos/48.pdf [Accessed January 10, 2012]

RAPPERT, B., Webster, A., Charles, D. (1999). Making sense of diversity and reluctance. Research Policy, 28(8), 873-890.

RATTEN,V. (20 I la).Sport-based entrepreneurship: towards a new theory of entrepreneurship and sport management. International Entrepreneurship and Management Journal, 7(I). 57-69.

RATTEN, V. (20 I l b).Social entrepreneurship and innovation in sports. International Journal of Social Entrepreneurship and Innovation. I (I), 42-54.

SHANE, S. (2004). Academic Entrepreneurship: University Spin-offs and Wealth Creation. (First ed.). Edward Elgar. Northampton, MA.

SPILLING, O. R. (1996). The entrepreneurial system: On entrepreneurship in the context of a mega-event. Journal of Business Research, 36(I), 9I-I03.

STEFFENSEN, M., Rogers, E. M., Speakman, K. (2000).Spin offs from research centers at a research university. Journal of Business Venturing, I5(I), 93-I I I.

TERRA, B. (1999). Escritórios de Transferência de Tecnologia em Universidades e Institutos de Pesquisa Públicos: Uma Proposta Institucional. PhD Thesis, UFRJ/COPPE/PEP/ITOI.
TERRA, B., Batista, L.A., Almeida, M., Campos, S. R. C. (20I I). A oportunidade de inovação no esporte é nossa! Polem!ca, IO(I), 74-90. 